\title{
Molecular and serological investigation of border disease virus infection in sheep in the Kars District of Turkey
}

\author{
Volkan Yilmaz, Yakup Yildirim, Nuvit Coskun \\ University of Kafkas, Faculty of Veterinary Medicine, Department of Virology, Kars, Turkey \\ Received November 1, 2013 \\ Accepted April 24, 2014
}

\begin{abstract}
This study is a serological and virological examination of the border disease virus (BDV) in sheep at 1-5 years of age from private small scale production units of less than 20 sheep per unit, in the Kars District of Turkey. For this purpose, blood sera from 460 sheep were tested for antibodies against BDV using a commercial enzyme-linked immunosorbent assay (ELISA). Since BDV causes persistent infection, antigen-ELISA was also performed for this agent. Seropositivity rate was detected to be $74.57 \%$. In addition, the BDV antigen was detected in one sample of seronegative sera $(0.85 \%)$. Reverse transcription polymerase chain reaction (RTPCR) technique was used to determine the presence of pestivirus nucleic acid by using 5'UTR primer pair. Pestivirus nucleic acid was found in 2 of 117 seronegative samples (1.71\%) by RTPCR. The results suggest that the infection was spreading in private small scale production units. Furthermore, recommendations for the control of BDV infection are presented. This study is the first molecular and serological study to determine viroprevalence and seroprevalence of BDV infection in sheep in the Kars District of Turkey.
\end{abstract}

$B D V$, ELISA, RT-PCR, seroprevalence, Turkey

Pestiviruses are enveloped, single stranded RNA viruses which belong to the Flaviviridae family. At present, the genus Pestivirus comprises bovine viral diarrhoea virus (BVDV) with its two genotypes BVDV1 and BVDV2, classical swine fever virus (CSFV), and border disease virus (BDV) (Moennig and Plagemann 1992). All four pestivirus species are closely related genetically and antigenically. Border disease (BD) is an enzootic disease of small ruminants and was first reported in 1959 from the border region of England and Wales (Hughes et al. 1959). Clinical signs in sheep include barren ewes, abortions, malformations, stillbirths, the birth of small weak lambs and persistent infections of the offspring. Affected lambs can show tremor, abnormal body conformation and hairy fleeces (so-called 'hairy-shaker' or 'fuzzy' lambs syndrome). BDV has also caused mucosal disease-like lesions in sheep (Monies et al. 2004). Transplacental infections of foetuses during the first trimester of pregnancy can result in immune tolerance and the surviving foetuses become persistently infected (Nettleton et al. 1992). Persistently infected (PI) sheep continually shed a large amount of virus in their body fluids. Furthermore, PI animals are the single most important source of infection for other animals. Since there is no effective commercial BDV vaccine, early detection and subsequent removal of PI animals is essential to a successful BDV control programme.

Laboratory diagnosis involves the detection ofBDV using virus isolation and immunoassay including antigen capture ELISA, immunofluorescence or other immunohistochemical techniques (Vilcek et al. 1997; Nettleton et al. 1998; Willoughby et al. 2006). Detection of BDV in animal clinical samples has been reported as difficult but not impossible in many publications. The RT-PCR has been a successful molecular tool for research purposes and diagnosis for BDV infections. This has allowed the detection of pestivirus RNA in a variety of clinical samples such as blood, tissues, serum and swabs (Edmondson et al. 2007).

Address for correspondence:

Dr. Volkan Yilmaz

Department of Virology

Veterinary Medicine University of Kafkas

Phone: +904742426807/5141

36300 Kars, Turkey

Fax: +904742426853

E-mail : volkankara1980@hotmail.com

http://actavet.vfu.cz/ 
Several regions of the viral genome have been used for the genetic typing of pestiviruses. At present, the 5' UTR, Npro and E2 regions are most often used (Strong et al. 2009). In recent years, it was announced that BDV circulation in sheep might be a new subgroup in Turkey. But there was no further extensive investigation in Turkey to determine the genetic type of BDV.

In this study, the seroprevalence and viroprevalence of BDV infection, which has been shown to be active in western Turkey, was determined by ELISA in sheep in the Kars District in North-eastern Anatolia. In addition, pestivirus nucleic acid was investigated in seronegative samples using RT-PCR. These virological and seroepizootological data demonstrate the occurrence of BDV in private small scale production units and emphasize the necessity of effective control measures. This is the first report confirming the occurrence of BDV infection in sheep in the Kars District of Turkey.

\begin{abstract}
Materials and Methods
Clinical samples

Blood samples were collected from 460 local sheep randomly, without clinical signs of the disease between November in 2012 to March in 2013 in private small scale production units $(<20$ sheep) in the Kars District of Turkey (Plate I, Fig. 1). The age of animals varied from 1 to 5 years. Blood samples were taken from the jugular vein. Blood tubes (without EDTA) were centrifuged at 3,000 $\times \mathrm{g}$ for $10 \mathrm{~min}$, and serum samples were transferred to sterile tubes and stored in $-20{ }^{\circ} \mathrm{C}$ until used.
\end{abstract}

Enzyme Linked Immunosorbent Assay (ELISA)

Commercial ELISA (Pourquier ELISA BVD/MD/BD P80, France) used for the detection of antibodies against BDV was carried out according to the manufacturer's instructions. A commercial ELISA kit (BVDV Ag Serum Plus HerdChek IDEXX Laboratories Westbrook, Maine 04092, USA) detecting E $^{\text {rns }}$ antigen in serum was used in the study according to the manufacturer's instructions. Both ELISA results were analyzed and calculated with an automated ELISA reader at $450 \mathrm{~nm}$.

Reverse Transcription Polymerase Chain Reaction (RT-PCR)

From seronegative samples, viral RNA was extracted using a GeneJet Viral DNA and RNA Purification Kit (Thermo Scientific, Waltham, MA, USA), according to the manufacturer's recommendation. The follow-up cDNA synthesis was carried out using a first strand cDNA synthesis Kit (Fermentas, Lituhania) as described by the manufacturer's protocol. Amplification of cDNAs by PCR was performed using the primer pairs 324/326 for 5'UTR (Vilcek et al. 1997). Five microlitres of each PCR product were analyzed on 1\% agarose (Prona, Spain) gel containing ethidium bromide (Sigma, USA). The NADL strain of BVDV obtained from the Ankara University Faculty of Veterinary Medicine Virology Department was used as positive control.

\title{
Results
}

A total of 460 serum samples were tested for BDV specific antibodies using ELISA. Overall results revealed that $74.56 \%(343 / 460)$ of the sheep sampled were BDV seropositive, while $25.43 \%$ of the samples (117/460) did not have antibodies aganist BDV. To determine persistently infected sheep, serum samples with no antibody response to $\mathrm{p} 80$ protein were tested for viral antigen. For this purpose, 117 seronegative samples were tested for $\mathrm{E}^{\text {rns }}$ antigen. In this study 1 of $117(0.85 \%)$ seronegative samples was antigen positive. The rate of virus infected animals that did not show antibody response against BDV in the sampling time was calculated to be $0.21 \%(1 / 460)$. To determine the BDV antigen, 117 seronegative samples were tested by RT-PCR and 2 of 117 seronegative samples were detected as a positive (1.7\%) (Plate I, Fig. 2).

\section{Discussion}

Numerous studies (Burgu et al. 1987; Burgu et al. 2001; Okur-Gumuşova et al. 2006; Hasircioglu et al. 2009; Azkur et al. 2011; Ozan et al. 2012) conducted with regard to the pestivirus infection in Turkey have demonstrated that the infection is widespread in 
populations of sheep and goats. These studies have reported that in various regions of Turkey pestivirus seroprevalence varies between $18.94-90.27 \%$ in sheep, and $5.7-65.7 \%$ in goats. This study is the first one to determine the seroprevalence of BDV in randomly sampled sheep in the Kars District of Turkey. The location for the study was chosen because Kars is located in the middle of an animal transit route between North-East Anatolia and Caucasus functioning as a bridge between Asia and Europe. The seropositivity of collected blood samples was found to be $74.56 \%$. This percentage is higher than the percentages found in studies conducted in past years (Burgu et al. 1987; Okur-Gumuşova et al. 2006; Hasircioglu et al. 2009) and is similar to the percentages reported by Azkur et al. (2011). Many factors such as the structure of the herd sampled, individual and regional differences as well as sensitivity of the tests used may affect the results. Okur-Gumusova et al. (2006) reported significant differences among the prevalence rates of pestivirus in coastal and inland areas of Turkey due to climate characteristics, and climate factors could play a major role in the spreading of the virus. Another reason for the higher percentage of pestiviruses in that region can be the use of live vaccines for the purpose of the control programme for some viral infections, e.g. peste des petits ruminants, sheep and goat pox, and etc. Pestiviruses are frequent contaminants of modified live virus vaccines produced on primary ovine and bovine cells, and may play a role in pestivirus maintenance and/or dissemination in the region.

Many virological studies for pestiviruses have been performed in Turkey. The presence of pestiviruses has been reported between $0.9 \%$ and $4.37 \%$ in small ruminants in a different part of Turkey (Burgu et al. 1987; Burgu et al. 2001; Hasircioglu et al. 2009; Oguzoglu et al. 2009; Azkur et al. 2011; Ozan et al. 2012). Krametter-Froetscher et al. (2009) reported a $0.32 \%$ prevalence of sheep pestivirus PI, and a $0.08 \%$ prevalence of goat pestivirus PI. Valdazo-Gonzalez et al. (2008) found a $0.24 \%$ prevalence of PI sheep in Spanish lambs. Azkur et al. (2011) reported a 4.37\% prevalence of sheep pestivirus PI in the Kirıkkale Province of Turkey. This study found a lower rate of PI sheep compared to the ones reported above. Our results indicate a $0.21 \%$ rate of virus infected sheep in the Kars District of Turkey. In Turkey, there is no special effort to detect PI animals in herds and no efforts are exerted to eliminate sheep with PI pestivirus . Consequently, there are no specific data on the frequency rate of PI sheep with pestivirus in the Kars District of Turkey.

In the Kars District, the presence of BVDV in cattle was reported in a previous serologic study carried out by Y1ldirım et al. (2011). Both BVDV and BDV can infect sheep and cattle. BDV prevalence in sheep could be a major risk factor for pestiviral infection of other species, particularly cattle that share communal pastures with sheep (Berriatua et al. 2006). In this region, this situation should be considered in the control strategy, and animal owners should be informed with respect to BDV infections. In our study, we also observed that sheep had the possibility of contact with cows.

A previous study comparing RT-PCR with ELISA and cell culture immunoperoxidase tests for the detection of ruminant pestivirus infections found RT-PCR to be more sensitive compared to the other tests (Horner et al. 1995). In this study, results indicated that from a total of 117 seronegative samples, $1(0.85 \%)$ and $2(1.7 \%)$ were positive for presence of BDV by antigen capture ELISA and RT-PCR assay, respectively. Our results showed that the molecular method was more sensitive than antigen capture ELISA.

Pestivirus control programs must first identify and remove PI animals from the breeding herd and prevent the infection of susceptible pregnant ewes. As a control procedure, it may be advised that persistently infected animals can be kept together with other animals in the flock previous to gestation to reveal flock immunity and to prevent exposing sheep or goats to infection during pregnancy. Close herding for at least 3 weeks, ideally indoors, is necessary for pestivirus to spread efficiently, but exposure should stop two months before 
the start of the breeding season (Nettleton and Brebner 1998). Although immunization efforts have been successfully carried out in many countries to bring BVDV infections under control, still more work remains to be done in the fight against BVDV infections. There are no known BVD immunizations available other than commercial immunization produced in Europe, and sheep immunized with BVD immunizations only receive partial protection. An ideal vaccine should be suitable for administration to females before breeding for the prevention of transplacental infection. Although some researchers propose the use of BVDV vaccines for BDV infection, antigenic diversity of field BD viruses must be considered. In addition, several modified live veterinary vaccines produced in sheep cell or containing sheep serum are potentially dangerous because of pestivirus contamination. The vaccines were based on different combinations of identified variations among BVDV isolates in the country. Most BVDV vaccines on the market in many countries, including in Turkey, contained BVDV 1-a and 1-b strains, some of them in combination with a BVDV 2 strain (Ridpath 2005). Ideally, a pestivirus control programme for Turkey should use a vaccine that contains not only BVDV1 strains but also BVDV2. For efficacious BVDV immunization and protection in Turkey, predominant BVDV1 subgenotypes (1-1 and 1-f) are clear vaccine candidates (Oguzoglu et al. 2009).

In conclusion, the results obtained in the present study showed that BDV infection is common in the North-Eastern Anatolia region, which is the most important cattle and sheep production area in Turkey. Also, the widespread distribution of BDV in the region requires the implementation of BDV control programmes based on identifying and eliminating PI animals, and highlights the potential risk of sheep as a virus reservoir for other species. Furthermore, animal movement (entrance of contraband animals or transfers between operations or from neighbouring countries via importation) should be carefully monitored to prevent the spread of the disease to a larger population. Molecular genetic typing of $\mathrm{BDV}$ is important for designing and constructing effective control strategies involving vaccination. Therefore, in the future, these results can be reflected more thanks to the studies on molecular typing of BDV in small ruminants in this region.

\section{Acknowledgements}

This project was supported by the Commission for the Scientific Research Projects of Kafkas Univertsity (2012-VF-58).

\section{References}

Azkur AK, Gazyagci S, Aslan ME, Unal N 2011: Molecular and serological characterization of pestivirus infection among sheep in Kirikkale, Turkey. Kafkas Univ Vet Fak Derg 17 (Suppl-A): S83-S92

Berriatua E, Barandika JF, Aduriz G, Hurtado A, Estevez L, Atxaerandio R, Garcia-Perez AL 2006: Flockprevalence of border disease virus infection in Basque dairy-sheep estimated by bulk-tank milk analysis. Vet Microbiol 118: $37-46$

Burgu I, Ozturk F, Akca Y, Toker A, Frey H-R, Liess B 1987: Investigations on the occurence and impact of bovine viral diarrhea (BVD) virus infections in sheep in Turkey. Dtsch Tierarztl Wochenschr 94: 292-294

Burgu I, Akca Y, Alkan F, Ozkul A, Karaoglu T, Bilge-dagalp S, Oguzoglu TC, Yesilbag K 2001: The serological and virological investigations and pathogenesis of BVDV infection in sheep during pre- and post-partum periods. Turk J Vet Anim Sci 25: 551-558

Edmondson MA, Givens MD, Walz PH, Gard JA, Stringfellow DA, Carson RL 2007: Comparison of tests for detection of bovine viral diarrhea virus in diagnostic samples. J Vet Diagn Invest 19: 376-381

Hasircioglu S, Kale M, Acar A 2009: Investigation of pestiviruses infections in aborted sheep and goats in Burdur region. Kafkas Univ Vet Fak Derg 15: 163-167

Horner GW, Tham KM, Orr D, Ralston J, Rowe S, Houghton T 1995: Comparison of an antigen capture enzymelinked assay with reverse transcription polymerase chain reaction and cell culture immunoperoxidase tests for the diagnosis of ruminant pestivirus infections. Vet Microbiol 43: 75-84. doi:10.1016/0378-1135(94)00080-G

Hughes LE, Kerschaw GP, Shaw IG 1959: Border disease. Vet Rec 71: 313-317

Krametter-Froetscher R, Duenser M, Preyler B, Theiner A, Benetka V, Moestl K, Baumgartner W 2009: Pestivirus infection in sheep and goats in West Austria. Vet J 186: 342-346 
Moennig V, Plagemann GW 1992: The pestiviruses. Adv Virus Res 41: 53-98

Monies RJ, Paton DJ, Vilcek S 2004: Mucosal disease-like lesions in sheep infected with Border disease virus. Vet Rec 155: 765-769

Nettleton PF, Gilmour JS, Herring JA, Sinclair JA 1992: The production and survival of lambs persistently infected with border disease virus. Comp Immunol Microbiol Infect Dis 15: 179-188

Nettleton PF, Gilray JA, Russo P, Dlissi E 1998: Border disease of sheep and goats. Vet Res 29: 327-340

Nettleton PF, Brebner J 1998: Border disease. In: Rodolakis A, Nettleton P, Benkirane A (Eds): Manual for Laboratory Diagnosis of İnfectious Abortions in Small Ruminants. FAO, Rome, pp.169-181

Okur-Gumusova S, Yazici Z, Albayrak H 2006: Pestivirus seroprevalance in sheep populations from inland and coastal zones of Turkey. Rev Med Vet 157: 22-25

Oguzoglu TC, Tan MT, Toplu N, Demir AB, Bilge-Dagalp S, Karaoglu T, Ozkul A, Alkan F, Burgu I, Haas L, Greiser-Wilke I 2009: Border disease virus (BDV) infections of small ruminants in Turkey: A new BDV subgroup? Vet Microbiol 135: 374-379

Ozan E, Turan MH, Albayrak H, Cavunt A 2012: Serological determination of pestivirus, bluetongue virus and peste des petits ruminants virus in small ruminants in Samsun Province of Turkey. Atatürk Üniversitesi Vet Bil Derg 7: 27-33

Paton DJ 1995: Pestivirus diversity. J Comp Pathol 112: 215-236

Ridpath JF 2005: Practical significance of heterogeneity among BVDV strains: Impact of biotype and genotype on U.S. control programs. Prev Vet Med 72: 17-30

Strong R, La Rocca SA, Ibata G, Sandvik T 2009: Antigenic and genetic characterisation of border disease viruses isolated from UK cattle. Vet Microbiol 141: 208-215

Vilcek S, Nettleton PF, Paton DJ, Belak S 1997: Molecular characterization of ovine pestiviruses. J Gen Virol 78: $725-735$

Valdazo-Gonzalez B, Alvarez M, Sandvik T 2008: Prevalence of border disease virus in Spanish lambs. Vet Microbiol 128: 269-278

Willoughby K, Valdazo-Gonzalez B, Maley M, Gilray J, Nettleton PF 2006: Development of a real time RT-PCR to detect and type ovine pestiviruses. J Virol Methods 132: 187-194

Yildirim Y, Yilmaz V, Kalaycioglu AT, Dagalp SB, Majarashin Faraji AR, Celebi O, Akca D 2011: An investigation of a possible involvement of BVDV, BHV-1 and BHV-4 infections in abortion of dairy cattle in Kars District of Turkey. Kafkas Univ Vet Fak Derg 17: 879-883 
Plate I

Yilmaz V. et al.: Molecular... pp. 175-179

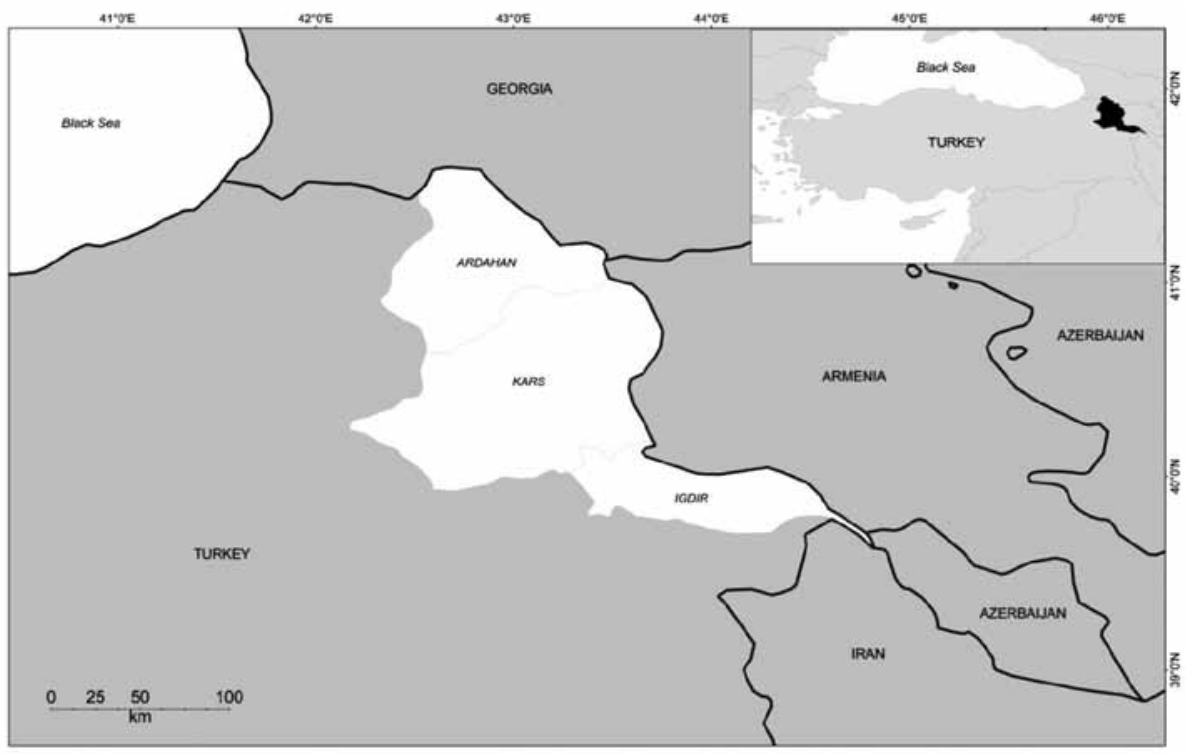

Fig 1. Geographical location of the Turkish provinces in which the study was performed

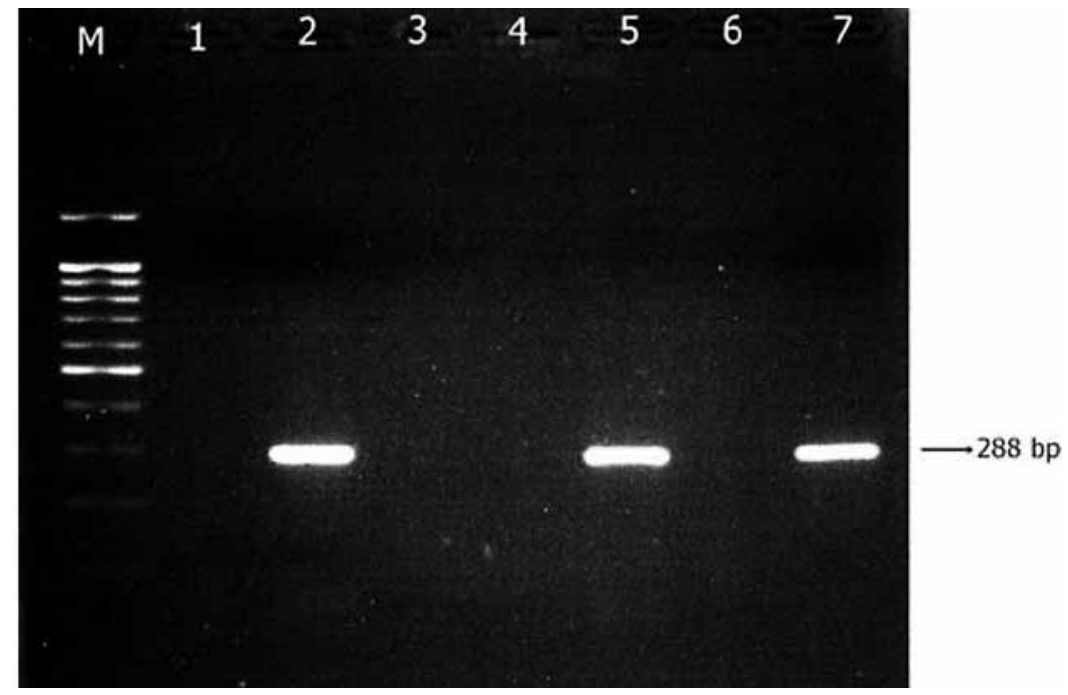

Fig 2. The result of RT-PCR in seronegative samples.

Column M: 100 bp DNA Ladder; columns 1, 3, 4: negative samples; columns 2, 5: positive samples, column 6: negative control; column 7: positive control (288bp) 